\title{
Segmented Arrangement of Borrelia duttonii DNA and Location of Variant Surface Antigen Genes
}

\author{
By LYN J. HAYES,,$^{1,2}$ DAVID J. M. WRIGHT² AND \\ LEONARD C. ARCHARD ${ }^{1 *}$ \\ Departments of ${ }^{1}$ Biochemistry and ${ }^{2}$ Medical Microbiology, Charing Cross and Westminster \\ Medical School, London W6 8RP, UK
}

(Received 20 November 1987; revised 17 February 1988)

\begin{abstract}
The DNA of an isolate of Borrelia duttonii, an agent of relapsing fever is present as seven major species ranging in size from $10 \mathrm{~kb}$ to greater than $150 \mathrm{~kb}$. Additionally, this isolate contains low copy number species, both smaller and larger than these seven major elements. No one of these individual DNA species obviously corresponds to the bacterial chromosome, unlike the situation in Borrelia hermsii, another relapsing fever Borrelia. Thus it appears that $B$. duttonii has a unique segmented arrangement of its genetic material. Cloned DNA fragments containing coding sequences specific for variant surface antigens of $B$. duttonii hybridize to a closely migrating, high copy number subset of these genetic elements.
\end{abstract}

\section{INTRODUCTION}

The spirochaete Borrelia duttonii is the agent of tick-borne human relapsing fever in East Africa (Burgdorfer, 1976). The vertebrate host is inoculated with the organism by the bite of the infected vector. Within a few days the organism multiplies causing bacteraemia, which is then cleared by the host immune system. A small proportion of spirochaetes escape the immune response by expression of an altered major surface antigen. Thus, a new population of antigenically different spirochaetes arises, and the patient relapses. This cycle recurs at 4-10 d intervals, until either the infection is resolved or the patient dies (Felsenfeld, 1971).

Borrelia hermsii, the agent of tick-borne relapsing fever in North America, has a repertoire of at least 26 variant surface antigens (VSAgs; Stoenner et al., 1982) and partial amino acid sequences of two of these VSAgs have been determined (Barstad et al., 1985). The N-termini of cyanogen bromide fragments of these two antigens have several short peptide sequences in common. We have used a conserved seven amino acid sequence to derive the sequence of a 20 residue synthetic mixed oligonucleotide specific for these two VSAgs of $B$. hermsii.

Our long-term aims are to identify and isolate genes encoding VSAgs of the East African agent, $B$. duttonii, and to investigate their different arrangements on the genomes of $B$. duttonii serotypes. We now describe the use of a synthetic mixed oligonucleotide derived from the conserved amino acid sequence of $B$. hermsii VSAgs to probe $B$. duttonii DNA for sequences homologous either at the DNA level or at the amino acid level with those of $B$. hermsii. We also describe the unusual segmented arrangement of the $B$. duttonii genome, and the distribution of DNA sequences recognized by this VSAg-specific probe on subgenomic elements.

\section{METHODS}

Growth of B. duttonii. A laboratory-adapted Wellcome mouse strain of B. duttonii was used. A pure culture was obtained by dilution past extinction in CBA/CA mice, and then amplified for DNA preparation in CB/CA mice. $B$. duttonii does not grow well in currently available media.

\footnotetext{
Abbreviations: VSAg, variant surface antigen; FIGE, field inversion gel electrophoresis; PFGE, pulsed field gradient electrophoresis; TE, $10 \mathrm{~mm}$-Tris/HCl, $1 \mathrm{~mm}$-EDTA buffer.
} 
Preparation of $B$. duttonii DNA. Infected mouse blood was harvested into Krebs saline. Spirochaetes were separated from mouse cells by centrifugation at $60 \mathrm{~g}$ for $15 \mathrm{~min}$, then pelleted by centrifugation at $2000 \mathrm{~g}$ for $15 \mathrm{~min}$. The pellet was washed in $10 \times \mathrm{TE}(1 \times \mathrm{TE}$ is $10 \mathrm{mM}$-Tris/ $\mathrm{HCl}, 1 \mathrm{mM}$-EDTA $) \mathrm{pH} 8.0$, and resuspended in $100 \mathrm{~mm}-\mathrm{Tris} / \mathrm{HCl}$ (pH 8.0), $60 \mathrm{~mm}$-EDTA; SDS was then added to $5 \%$ (w/v). Proteinase $\mathrm{K}$ (BoehringerMannheim) was added to $50 \mu \mathrm{g} \mathrm{ml}^{-1}$, and the suspension was incubated for $3 \mathrm{~h}$ at $55^{\circ} \mathrm{C}$. Proteins were removed by repeated phenol extractions and nucleic acid was precipitated with ethanol, spooled out on a glass rod and redissolved in TE buffer. After incubation with boiled RNAase 1 (Pharmacia; $50 \mu \mathrm{g} \mathrm{ml}^{-1}$ for $30 \mathrm{~min}$ at $37^{\circ} \mathrm{C}$ ), and further phenol extractions, DNA was reprecipitated with ethanol, collected by centrifugation $(4500 \mathrm{~g}, 10 \mathrm{~min})$ and redissolved in TE buffer.

Oligonucleotide synthesis. The oligonucleotide was synthesized by the solid phase triester method using a Pharmacia gene assembler. The nucleotide sequence is as follows

\section{Amino acid sequence: Ser Ala Glu Asn Ala Phe Tyr (Barstad et al., 1985) Oligonucleotide sequence: $3^{\prime} \mathrm{CN}$ CGN CTY TTR CGN AAR ATR 5'}

where $\mathrm{N}=$ any nucleotide, $\mathrm{Y}=$ pyrimidine, $\mathrm{R}=$ purine, degeneracy $=1024$. We designed the mixed oligonucleotide to include all possible coding permutations for the conserved seven amino acid sequence.

Restriction endonuclease cleavage, electrophoresis and Southern transfer of DNA. B. duttonii DNA or recombinant plasmids were cleaved with endonuclease PstI (Pharmacia), then electrophoresed in $1 \%(\mathrm{w} / \mathrm{v})$ agarose gels (BRL Ultra Pure) for $2-4 \mathrm{~h}$ at $70 \mathrm{~V}\left(5 \mathrm{~V} \mathrm{~cm}^{-1}\right)$ at room temperature in $1 \times \mathrm{E}$ buffer $(0.04 \mathrm{M}$-Tris/HCl, 0.002 $\mathrm{M}$-EDTA, $\mathrm{pH} 7.7$ ). DNA was denatured by soaking gels in $0.5 \mathrm{M}-\mathrm{NaOH}, 1.5 \mathrm{M}-\mathrm{NaCl}$ for $1 \mathrm{~h}$ at room temperature, neutralized in $0.5 \mathrm{M}-\mathrm{Tris} / \mathrm{HCl}(\mathrm{pH} \mathrm{7.2)}, 1.5 \mathrm{M}-\mathrm{NaCl}$ for $30 \mathrm{~min}$ at room temperature and transferred to Hybond-N (Amersham) (Southern, 1975). Non-digested B. duttonii DNA was electrophoresed in $0.6 \%(\mathrm{w} / \mathrm{v})$ agarose gels for $40 \mathrm{~h}$ at $100 \mathrm{~V}\left(5 \mathrm{~V} \mathrm{~cm}^{-1}\right)$ in $1 \times \mathrm{E}$ buffer using a field inversion gel electrophoresis (FIGE) apparatus (Porter et al., 1988). The switching ratio was $3 / 2$, with an initial forwards interval of $0.75 \mathrm{~s}$, and a final forwards interval of $3 \mathrm{~s}$, at a running temperature of $17^{\circ} \mathrm{C}$. Alternatively, non-digested DNA was electrophoresed for $16 \mathrm{~h}$ at $330 \mathrm{~V}$ $\left(16.5 \mathrm{~V} \mathrm{~cm}^{-1}\right)$ in $1 \mathrm{M}$-Tris/borate buffer, $\mathrm{pH} 8.0$, using a pulsed field gradient electrophoresis (PFGE) apparatus (LKB Pulsaphor system), with a switching time of $2 \mathrm{~s}$, at a running temperature of $15^{\circ} \mathrm{C}$. DNA was depurinated in $0.25 \mathrm{M}-\mathrm{HCl}$ for $15 \mathrm{~min}$, denatured, neutralized and transferred as above.

Isolation, endonuclease cleavage and end-labelling of the $24 \mathrm{~kb} B$. duttonii genetic element. Non-digested $B$. duttonii DNA was electrophoresed as described above in low-melting-point agarose, and the $24 \mathrm{~kb}$ segment was excised from the gel and purified by phenol extraction and ethanol precipitation. The purified DNA was cleaved with the restriction enzyme HindIII, and the resulting fragments were end-labelled with [ $\left.{ }^{32} \mathrm{P}\right] \mathrm{dCTP}$ using the Klenow enzyme. Labelled fragments were electrophoresed, transferred to nylon membranes and autoradiographed.

Molecular cloning of DNA fragments. B. duttonii DNA cleaved with PstI was separated by gel electrophoresis on a $1 \%$ agarose gel (Pharmacia agarose). A section of gel containing fragments in the size range $2.0-5 \cdot 6 \mathrm{~kb}$ was excised and fragments were electro-eluted from the gel slice (Maniatis et al., 1982) and recovered by ethanol precipitation. Fragments were ligated to PstI cleaved and dephosphorylated pBR322 (New England Biolabs) overnight at $20^{\circ} \mathrm{C}$, using T4 ligase (10 units, Amersham; Maniatis et al., 1982). Escherichia coli HB101 was transformed with the recombinant plasmids by the standard high-efficiency technique of Hanahan (1985). Tetracycline-resistant colonies were grown in broth culture, and small-scale plasmid preparations were made (Birnboim \& Doly, 1979). Recombinant plasmids were cleaved, electrophoresed and blotted as described above. Southern blots were screened by hybridization tc the synthetic oligonucleotide probe (see below).

Plasmid DNA preparation. Cultures of $E$. coli HB101 transformants were grown to early exponential phase. Plasmids were prepared by the alkaline lysis method (Ish-Horowicz \& Burke, 1981).

Labelling hybridization probes with ${ }^{32} P$. The VSAg-specific mixed oligonucleotide $(100 \mathrm{ng})$ was end-labelled with $100 \mu \mathrm{Ci}\left(3.7 \mathrm{MBq}\right.$ ) [ $\left.{ }^{32} \mathrm{P}\right] \mathrm{ATP}$ (New England Nuclear), and T4 kinase (6 units, Amersham) in $50 \mathrm{~mm}-\mathrm{Tris} / \mathrm{HCl}$ (pH 7.6), $10 \mathrm{mM}-\mathrm{MgCl}_{2}, 10 \mathrm{mM}$-2-mercaptoethanol, for $1 \mathrm{~h}$ at $37^{\circ} \mathrm{C}$. Non-incorporated nucleotides were removed by exclusion chromatography on Sephadex G-25 (Pharmacia). Recombinant plasmids, vector pBR322, $\lambda$ phage DNA and total $B$. duttonii DNA (50 ng each) were labelled with $20 \mu \mathrm{Ci}(740 \mathrm{kBq})\left[{ }^{32} \mathrm{P}\right] \mathrm{dCTP}$, using the $\mathrm{Klenow}$ fragment of DNA polymerase I and random oligonucleotides as primers (Feinberg \& Vogelstein, 1983). These probes were recovered by chromatography on Sephadex G-50 (Pharmacia). Specific activities of hybridization probes were routinely $>10^{8}$ d.p.m. $\mu \mathrm{g}^{-1}$.

Hybridization and autoradiography. Filters probed with the oligonucleotide were prehybridized for $3 \mathrm{~h}$ in $6 \times$ SSC $(1 \times$ SSC is $0.15 \mathrm{M}-\mathrm{NaCl}, 0.015 \mathrm{M}$-sodium citrate, pH 7.6), $5 \times$ Denhardt's solution (per litre: Ficoll, $1 \mathrm{~g}$; polyvinyl pyrrolidone, $1 \mathrm{~g}$; bovine serum albumin, Fraction $\mathrm{V}, 1 \mathrm{~g}), 0 \cdot 1 \%(\mathrm{w} / \mathrm{v}) \mathrm{SDS}, 5 \mathrm{mM}$-EDTA, at $45^{\circ} \mathrm{C}$, hybridized in $6 \times \mathrm{SSC}, 5 \times$ Denhardt's, $0.1 \%(\mathrm{w} / \mathrm{v}) \mathrm{SDS}, 5 \mathrm{mM}$-EDTA, $100 \mu \mathrm{g} \mathrm{E}$. coli tRNA ml ${ }^{-1}$ overnight at $45^{\circ} \mathrm{C}$, and washed in $6 \times \mathrm{SSC}, 0.1 \% \mathrm{SDS}, 5 \mathrm{~mm}$-EDTA for $3 \times 10 \mathrm{~min}$ at $45^{\circ} \mathrm{C}$. The predicted melting temperature of the mixed oligonucleotide is $52-66^{\circ} \mathrm{C}$. All other filters were prehybridized for $3 \mathrm{~h}$ in $6 \times \mathrm{SSC}, 5 \times$ Denhardt's, $0.1 \%(\mathrm{w} / \mathrm{v}) \mathrm{SDS}, 5 \mathrm{mM}$-EDTA at $65^{\circ} \mathrm{C}$, hybridized overnight at $65^{\circ} \mathrm{C}$ in $6 \times \mathrm{SSC}, 5 \times$ Denhardt's, 
$0 \cdot 1 \%(\mathrm{w} / \mathrm{v}) \mathrm{SDS}, 5 \mathrm{mM}$-EDTA plus $100 \mu \mathrm{g}$ sonicated denatured salmon sperm DNA ml${ }^{-1}$, and washed in $2 \times$ SSC, $0.1 \%(\mathrm{w} / \mathrm{v}) \mathrm{SDS}, 5 \mathrm{mM}$-EDTA for $30 \mathrm{~min}$ at $65^{\circ} \mathrm{C}$, then in $0.1 \times \mathrm{SSC}, 0.1 \%(\mathrm{w} / \mathrm{v}) \mathrm{SDS}, 5 \mathrm{mM}$-EDTA for $120 \mathrm{~min}$ at $65^{\circ} \mathrm{C}$. After washing, filters were air-dried and autoradiographed using Kodak X-Omat-AR and Fuji RX-100 film, at $-70^{\circ} \mathrm{C}$, with or without intensifying screens.

\section{Table 1. Densitometric scanning data from autoradiographs of Southern blots of $B$. duttonii $D N A$ fractions probed with homologous DNA}

Figures given are percentages of total integrals for each scan. Two pairs of closely migrating fractions, $E+F$ and $G+H$ were not sufficiently well separated to be differentiated by the densitometer, so each pair is classed together in this Table.

$\begin{array}{crc}\text { Fraction } & \begin{array}{c}\text { Size } \\ (\mathbf{k b})\end{array} & \begin{array}{c}\text { B. duttonii } \\ \text { DNA (\%) }\end{array} \\ \text { A } & >200 & 3 \cdot 43 \\ \text { B } & >200 & 5 \cdot 74 \\ \text { C } & 150 & 26.77 \\ \text { D } & 50 & 9 \cdot 31 \\ \text { E/F } & 34 / 33 & 13.28 \\ \text { G/H } & 28 / 27 & 7.6 \\ \text { I } & 24 & 23.33 \\ \text { J } & 10 & 4.21\end{array}$

\section{RESULTS}

Segmented arrangement of $B$. duttonii DNA

Unrestricted $B$. duttonii DNA subjected to FIGE (data not shown) or to PFGE revealed eight distinct species visible by ethidium bromide staining (Fig. $1 a$ ). Seven of these species, which virtually comigrated in conventional $1 \%$ agarose gels, formed a 'family' with apparent sizes ranging from $24 \mathrm{~kb}$ to $150 \mathrm{~kb}$ when separated by prolonged, low-voltage electrophoresis on soft gels followed by Southern blotting (see Fig. $1 b$, bands C to I). $\lambda$ DNA oligomers were used to estimate the sizes of the largest species in the family. The eighth species was smaller, comigrating with a $10 \mathrm{~kb}$ linear marker (see Fig. $1 b$, band J). Southern blotting additionally revealed two more very high molecular mass species which were not seen on the ethidium bromide stained gels (see Fig. $1 b$, bands A and B). Very little $B$. duttonii DNA remained at the origin of the gel, excluding the possibility that a majority chromosomal species is present but fails to migrate into the gel under these conditions. Densitometric scans of autoradiographs indicate that the family of seven species represents about $80 \%$ of the total DNA complement of $B$. duttonii, assuming that all size classes transfer with comparable efficiency (Table 1). Since the DNA was depurinated with $\mathrm{HCl}$ before transfer, we assume that the extent of hybridization represented by autoradiographic development is an accurate measure of the quantity of DNA contained in each species. Individual DNA species are not present in equimolar amounts; the family of seven smaller species, while variable between themselves are present at greater copy numbers than the two larger species. The same arrangement of genetic elements was observed in three pure cultures derived independently from a stock of $B$. duttonii passaged continuously in a strain of mouse that does not undergo relapses of the disease.

\section{Restriction endonuclease cleavage of the $24 \mathrm{~kb}$ genetic element}

To investigate the nature of the genetic elements contained in the family of seven closely migrating segments, we isolated the smallest, which migrates with an apparent size of $24 \mathrm{~kb}$, and cleaved it with HindIII (Fig. 2). If this element were a circular, supercoiled plasmid, then the mobility of the intact species would be aberrantly fast, and the sum of the sizes of the restriction fragments would be greater than $24 \mathrm{~kb}$. If the element were a relaxed circle then the intact species would migrate aberrantly slowly, and the sum of the restriction fragments would be less than $24 \mathrm{~kb}$. Fig. 2 shows that the sum of the HindIII restriction fragments of this element is compatible with a $24 \mathrm{~kb}$ species, and that the migration of the intact molecule accurately reflects its size, indicating that this is a linear genetic element. Additionally, Schwartz \& Cantor (1984) 
(a)
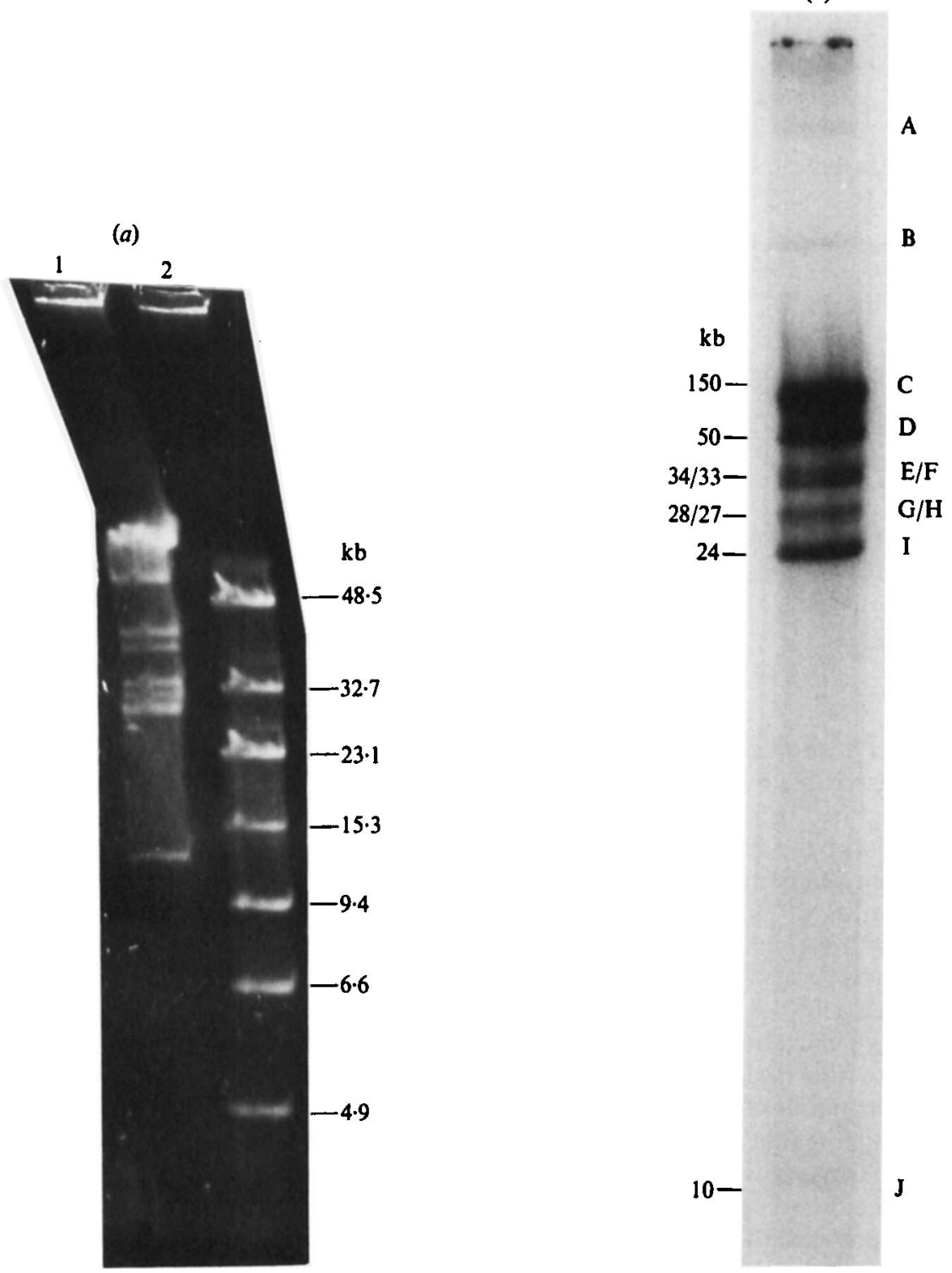

Fig. 1. (a) Uncleaved B. duttonii DNA separated by PFGE and stained with ethidium bromide. Lane 1, B. duttonii DNA. The largest smeared fragment visible corresponds to the $150 \mathrm{~kb}$ fragment $\mathrm{C}$ in $($ b); fragments $A$ and $B$ are not visible in this gel. Lane 2, Intact $\lambda$ DNA, $\lambda$ DNA digested with $S a I$ and $\lambda$ DNA digested with HindIII. (b) Uncleaved $B$. duttonii DNA separated by uni-directional electrophoresis, $30 \mathrm{~V}$ for $90 \mathrm{~h}$, through $0.6 \%$ agarose, then transferred to a nylon membrane and detected by hybridization to a ${ }^{32} \mathrm{P}$-labelled homologous total DNA probe. Two additional high molecular mass bands, A and B, not visible by ethidium bromide staining, are revealed.

have shown that large circular DNA molecules are virtually immobile in PFGE gels; this $24 \mathrm{~kb}$ genetic element is mobile in both FIGE and PFGE gels, supporting the conclusion that it is a linear species.

Identification and molecular cloning of DNA sequences encoding conserved features of VSAgs

Separated fragments of $P$ st I-cleaved B. duttonii genomic DNA were transferred by Southern blotting to nylon membranes. The filter was hybridized at low stringency with the VSAg- 


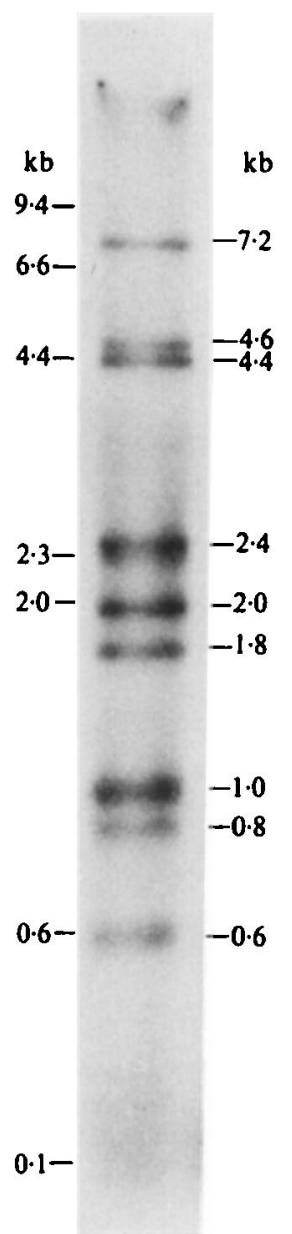

Fig. 2. The $24 \mathrm{~kb}$ genetic element of $B$. duttonii isolated, cleaved with HindIII, and end-labelled with [ ${ }^{32}$ P]dCTP using the Klenow fragment of DNA polymerase I. Labelled DNA was electrophoresed, transferred to a nylon membrane and autoradiographed. Values on the right indicate fragment sizes; the sum of the fragment sizes is $24.9 \mathrm{~kb}$. Values on the left refer to DNA size markers generated by HindIII cleavage of $\lambda$ DNA.

specific oligonucleotide mixture at a concentration of $10 \mathrm{ng} \mathrm{ml}^{-1}$. The oligonucleotide probe hybridized to PstI fragments of $B$. duttonii DNA at eight distinct locations on the filter (Fig. 3). Three of these lay within the size range $2-5 \mathrm{~kb}$, including the strongest signal at $4.3 \mathrm{~kb}$ and so $P$ st I fragments in this range were cloned randomly into pBR 322 and amplified in E. coli HB101. Inserts were excised with PstI and screened by hybridization with the VSAg-specific oligonucleotide. Seven were positive; three of these clones contained inserts of $2.4 \mathrm{~kb}$, one contained an insert of $4.0 \mathrm{~kb}$, and three contained inserts of $4.3 \mathrm{~kb}$. The VSAg-specific oligonucleotide did not hybridize to the pBR322 vector (Fig. 3). In further hybridizations, a cloned regulatory sequence of $B$. hermsii VSAgs (pRML7.1; Meier et al., 1985) hybridized to the $2.4 \mathrm{~kb}$ inserts and to the $4.3 \mathrm{~kb}$ inserts (data not shown), supporting the proposition that these cloned $B$. duttonii sequences are related to VSAg genes.

Inserts were excised with $P s t I$, separated from the vector by electrophoresis, and transferred to nylon membranes. The recombinants containing a $4.3 \mathrm{~kb}$ insert were additionally cleaved with HincII to avoid comigration with the vector. Each insert was tested for homology with every other by hybridization under highly stringent conditions. Hybridizations between inserts divide the recombinants into three classes, in that clones containing the $2.4 \mathrm{~kb}$ insert cross- 


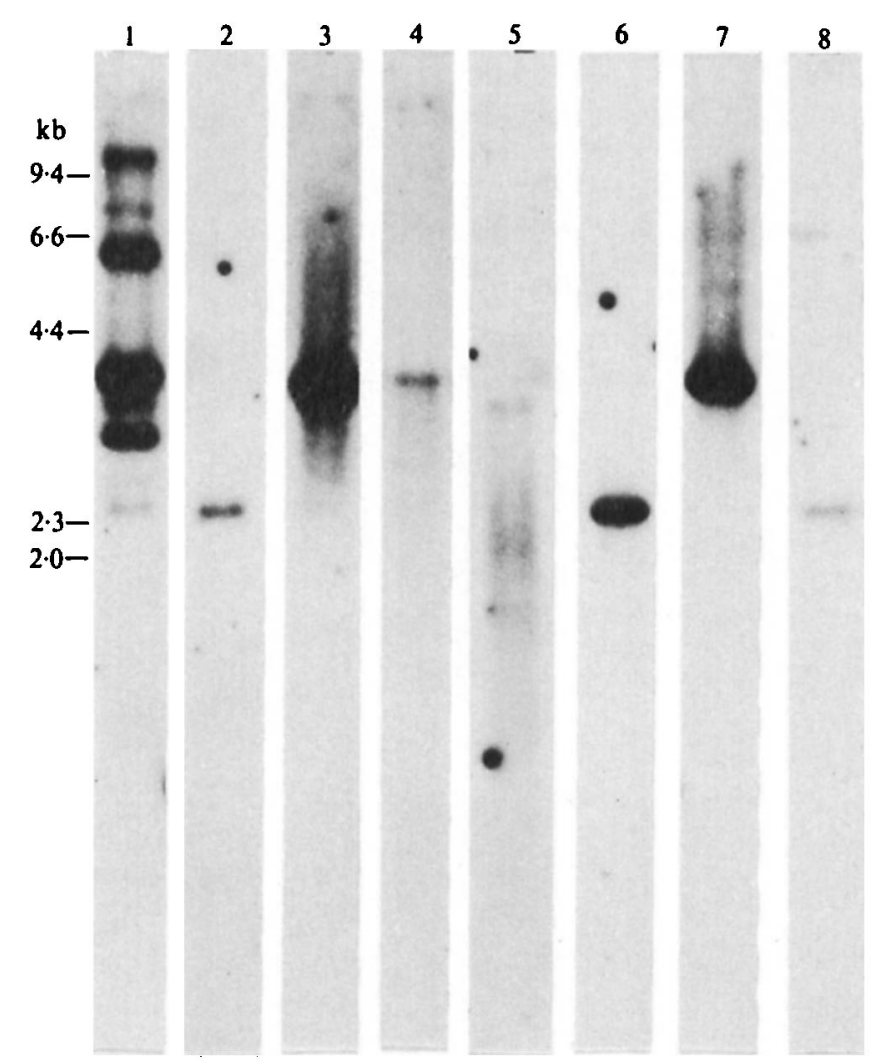

Fig. 3. Autoradiographs of total $B$. duttonii DNA cleaved with PstI and recombinants cleaved with Pst I, and hybridized with the VSAg-specific mixed oligonucleotide. Lane 1, total $B$. duttonii DNA; 2 , recombinant $6 ; 3$, recombinant $133 ; 4$, recombinant $166 ; 5$, recombinant $186 ; 6$, recombinant 204 ; 7 , recombinant $208 ; 8$, recombinant $\mathrm{J} 14$.

hybridize, and clones containing the $4.3 \mathrm{~kb}$ insert cross-hybridize; the clone containing the $4.0 \mathrm{~kb}$ insert shows no homology with other inserts under these conditions. These data, together with restriction endonuclease profiles, show that the $2.4 \mathrm{~kb}$ inserts are identical, and the $4.3 \mathrm{~kb}$ inserts are identical. Thus, a total of three different oligonucleotide selected sequences have been cloned; the cross-hybridization data show that these contain no shared sequences substantially larger than the sequence selected by the oligonucleotide probe.

\section{Probing uncleaved B. duttonii DNA}

The VSAg-specific oligonucleotide hybridized to each of the 'family' of seven segments of uncleaved $B$. duttonii DNA, but we were unable to detect hybridization of the oligonucleotide to either of the two very high molecular mass species (segments A and B) (data not shown). It is possible that we were unable to detect hybridization to these species because they occur at such low copy number with respect to the family of seven elements, as judged by hybridization with a total homologous DNA probe. Therefore, we cannot exclude the possibility that they contain sequences complementary to the oligonucleotide. Neither could we detect hybridization of the oligonucleotide to the $10 \mathrm{~kb}$ species (segment $\mathrm{J}$; data not shown).

Six of the recombinants hybridized to at least two of the 'family' of seven segments under high stringency conditions (Fig. 4). Recombinants containing the $2.4 \mathrm{~kb}$ insert all hybridized to the same subset of segments. Recombinants containing the $4.3 \mathrm{~kb}$ insert all hybridized to the same subset, which was different to that picked out by the $2.4 \mathrm{~kb}$ insert. Recombinant 186 , containing the $4.0 \mathrm{~kb}$ insert, hybridized to a single segment only. Groups of recombinants hybridized to different segments to varying degrees, which seemed to be independent of the quantity of DNA 


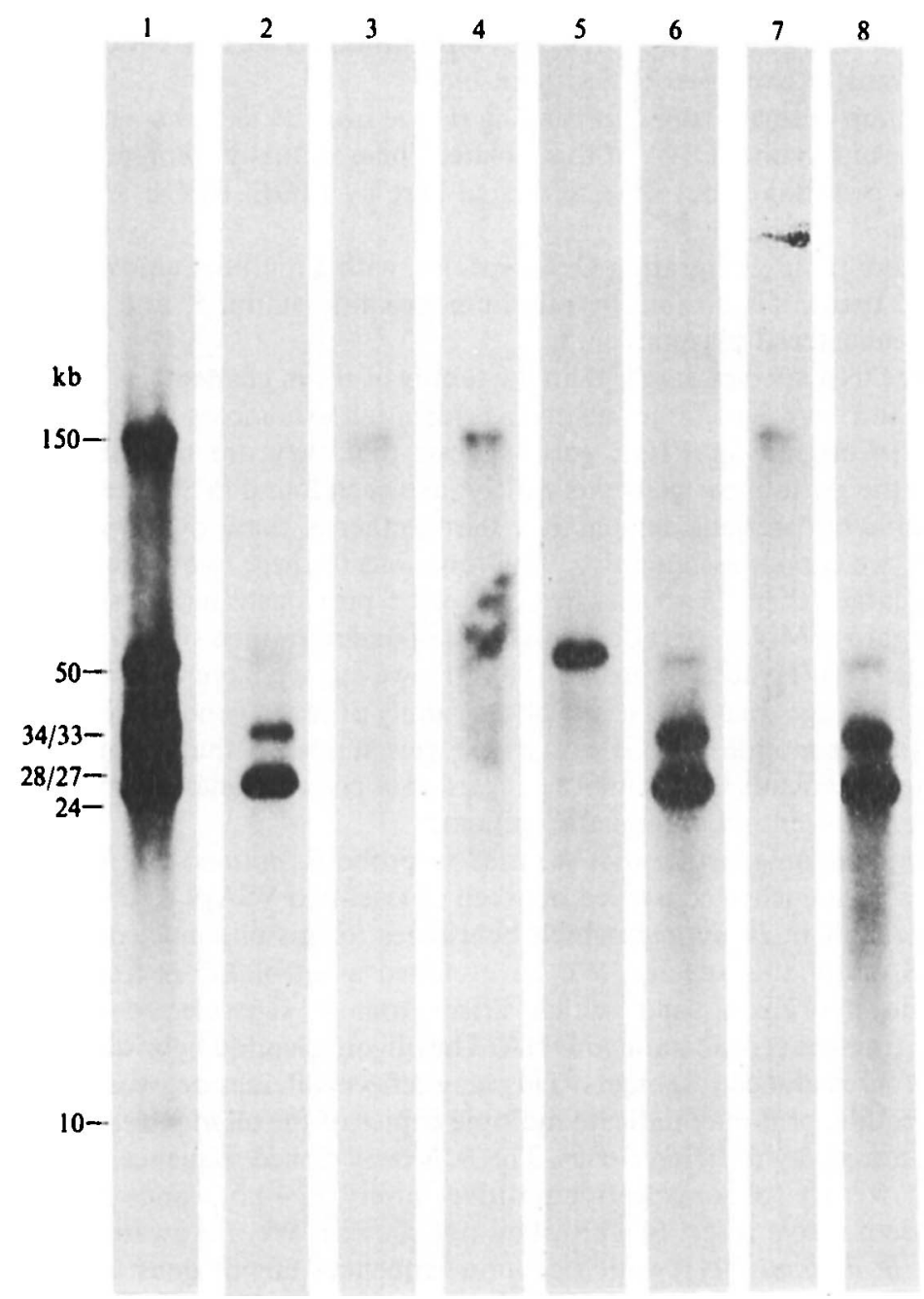

Fig. 4. Autoradiographs of total uncleaved $B$. duttonii DNA separated by FIGE, transferred to a nylon membrane and hybridized to an homologous DNA probe, or to each oligonucleotide-positive recombinant. Lane $1, B$. duttonii DNA probe; 2 , recombinant 6 probe; 3 , recombinant 133 probe; 4 , recombinant 166 probe; 5 , recombinant 186 probe; 6 , recombinant 204 probe; 7, recombinant 208 probe; 8 , recombinant $\mathrm{J} 14$ probe.

in each fraction. Under these high stringency conditions we did not detect hybridization of any recombinants to components $\mathrm{A}, \mathrm{B}$ or $\mathrm{J}$.

Southern blots of restriction fragments of total mouse genomic DNA were probed under appropriate conditions with the VSAg-specific oligonucleotide, the seven recombinant plasmids individually, or pBR322. None of the probes hybridized to the mouse DNA, nor did pBR322 hybridize to $B$. duttonii DNA (data not shown).

\section{DISCUSSION}

In B. hermsii, Plasterk et al. (1985) have demonstrated a series of linear plasmids in addition to an obvious DNA band of large but undetermined size which they considered to be the chromosome. In contrast, the genetic complement of $B$. duttonii consists of a number of distinct segments, not one of which can reasonably be designated as the chromosome. We have excluded 
the possibility of a large majority (presumed chromosomal) species which fails to migrate into the gel or to transfer from gels to Southern blots.

There is a group of seven segments ranging in size from 24 to $50 \mathrm{~kb}$ which together comprise more than $80 \%$ of the total DNA of this isolate. These virtually comigrate under conventional electrophoresis conditions, but were separated here by FIGE, PFGE and slow unidirectional electrophoresis.

A further more rapidly migrating DNA species, with a mobility equivalent to a $10 \mathrm{~kb}$ linear molecule, was barely discernible by ethidium bromide staining, and may correspond to a conventional eubacterial plasmid.

Two further DNA species, larger than the family of seven elements, were present at very low copy number, and were detectable only by hybridization to homologous DNA on Southern blots. Their ability to migrate in FIGE gels suggests that they are not circular, and they may correspond to the giant linear plasmids which have been found in Streptomyces (Kinashi et al., 1987). Control hybridizations demonstrate that neither of these two species is residual mouse DNA. As yet, we cannot assign any coding functions to these two large but minority species.

A plasmid larger than $23 \mathrm{~kb}$ has been reported previously in the spirochaete Treponema pallidum (Norgard \& Miller, 1981), and plasmids of undetermined size occur in Borrelia turicatae and Borrelia parkeri (Hyde \& Johnson, 1984). However, we have demonstrated by restriction endonuclease cleavage that at least one of the family of seven genetic elements of $B$. duttonii is linear and, as all are mobile in FIGE and PFGE gels, it is likely that the other six are also linear. As linear genetic elements they cannot be regarded as conventional plasmids. We conclude that they are parts of an entirely segmented genome.

The synthetic oligonucleotide that we used to probe $B$. duttonii DNA is directed against a seven amino acid sequence conserved between at least two VSAgs of $B$. hermsii. Since a DNA sequence is present in $B$. duttonii which hybridizes to this oligonucleotide, we presume it is related to VSAgs of this species. We have cloned a set of DNA fragments to which this oligonucleotide hybridizes, and which arise from a size-selected subset of restriction endonuclease fragments of $B$. duttonii DNA. The oligonucleotide hybridizes to different extents to each of the three cloned fragments. This may reflect different degrees of mis-matching with the oligonucleotide, or it may indicate multiple copies of the oligonucleotide selected sequence on the more strongly hybridizing clones. The $B$. hermsii cloned sequence, pRML 7.1, hybridizes to the most weakly oligonucleotide-positive insert $(2.4 \mathrm{~kb})$, and to the most strongly oligonucleotide-positive insert ( $4.3 \mathrm{~kb}$; data not shown). We are aware of other sizes of Pst fragments of $B$. duttonii DNA which contain sequences homologous with the VSAg-specific oligonucleotide, but are not included in our cloned fragments.

Initial selection of recombinants was by hybridization to the 20 residue VSAg-specific oligonucleotide; this hybridization is stable only at low temperature. The potential to encode the conserved amino acid sequence of borrelial VSAgs is therefore the only required common feature of these clones. In more stringent conditions, under which the oligonucleotide hybrid would not be stable, and which reveal sequence homologies over much longer stretches, the recombinants fall into three distinct groups, the members of each containing the same size of $B$. duttonii sequence. Recleavage of isolated inserts confirm that a total of three different $B$. duttonii sequences, each capable of encoding the conserved seven amino acid sequence of the VSAgs, have been recovered. The conclusion that these cloned $B$. duttonii sequences are related to genes encoding VSAgs is supported by our observation that two of these have sequence homology with the $B$. hermsii regulatory sequence described by Meier et al. (1985). The fact that these three cloned $B$. duttonii sequences do not cross-hybridize with each other under stringent conditions demonstrates that the coding sequence which is conserved between VSAgs is not extensive.

We have demonstrated that recombinant plasmids containing inserts selected by the oligonucleotide hybridize to different subsets of the family of seven genetic elements. The two large (greater than $150 \mathrm{~kb}$ ), low copy number species do not hybridize with any of our oligonucleotide-selected cloned sequences. The apparent VSAg-related sequences represented by recombinants containing the $2.4 \mathrm{~kb}$ insert, and by those containing the $4.3 \mathrm{~kb}$ insert hybridize to more than one of the family of seven genetic elements. This suggests that either the VSAg 
genes represented by these recombinants are duplicated on different genetic elements, or that these contain extensive areas of DNA homology with other genes distributed on different genetic elements. We have demonstrated that the genetic elements are not multimers of a single species, since they show different hybridization patterns with particular recombinant probes. They contain sequences related to structural genes essential for survival of the organism in the vertebrate host, so they cannot reasonably be considered to be episomal elements.

There is a striking similarity between the family of seven genetic elements in $B$. duttonii, and the 'mini-chromosomes' (50-150 kb) of African trypanosomes which are thought to provide additional chromosome ends and hence allow expansion of the telomeric surface glycoprotein gene population (Van der Ploeg et al., 1984). These mini-chromosomes are not found in related protozoa that do not undergo antigenic variation (Borst, 1986).

VSAg gene duplication is known to be part of the mechanism of antigenic variation in African trypanosomes (Hoeijimakers et al., 1980), and in Borrelia hermsii (Meier et al., 1985; Plasterk et al., 1985). In both organisms, copies of VSAg genes are duplicated between storage sites and expression sites. It is possible that this family of high copy number subgenomic elements which are stably maintained in $B$. duttonii provide a framework for high-frequency recombination of VSAg genes between multiple storage sites, and one or more expression sites.

We would like to thank Mr D. J. Frost for assistance with culturing the Borrelia; Dr A. G. Barbour for the kind gift of pRML7.1 and Mr C. D. Porter for constructing the FIGE apparatus. L. J.H. is the recipient of a SERC studentship.

\section{REFERENCES}

Barstad, P. A., Coligan, J. E., Raum, M. G. \& BARBOUR, A. G. (1985). Variable major proteins of Borrelia hermsii: epitope mapping and partial sequence analysis of $\mathrm{CNBr}$ peptides. Journal of Experimental Medicine 161, $1302-1314$.

Birnborm, H. C. \& DolY, J. (1979). Rapid alkaline extraction procedure for screening recombinant plasmid DNA. Nucleic Acids Research 7, 1513-1523.

BORST, P. (1986). Gêthe rearrangements controlling gene expression. Biochemistry International 12, 567591.

BURGDORFER, W. (1976). The epidemiology of relapsing fevers. In The Biology of Parasitic Spirochaetes, pp. 191-200. Edited by Russell C. Johnson. London: Academic Press.

Feinberg, A. P. \& Vogelstein, B. (1983). A technique for radiolabelling DNA restriction endonuclease fragments to high specific activity. Analytical Biochemistry 132, 6-13.

FeLSENFELd, O. (1971). Human borreliosis (relapsing fever). In Borrelia: Strains, Vectors, Human and Animal Borreliosis, pp. 98-112. St Louis: Warren H. Green.

HANAHAN, D. (1985). Techniques for transformation of E. coli. In DNA Cloning, vol. 1, pp. 109-135. Edited by D. M. Glover. Oxford: IRL Press.

hoeimimakers, J. H. J., Frasch, A. C. C., Bernards, A., Borst, P. \& Cross, G. A. M. (1980). Novel expression-linked copies of the genes for variant surface antigens in trypanosomes. Nature, London 284, 78-80.

HYde, F. W. \& Johnson, R. C. (1984). Genetic relationship of Lyme disease spirochetes to Borrelia, Treponema, and Leptospira spp. Journal of Clinical Microbiology 20, 151-154.

ISH-HoROWICZ, D. \& BURKE, J. R. (1981). Rapid and efficient cosmid cloning. Nucleic Acids Research 9, 2989-2998.
Kinashi, H., Shimaji, M. \& SaKai, A. (1987). Giant linear plasmids in Streptomyces which code for antibiotic biosynthesis genes. Nature, London 328, 454-456.

Maniatis, T., Fritsch, E. F. \& SAmbrook, J. (1982). Molecular Cloning: a Laboratory Manual, pp. 164165. Cold Spring Harbor, NY: Cold Spring Harbor Laboratory.

Meier, J. T., Simon, M. I. \& Barbour, A. G. (1985). Antigenic variation is associated with DNA rearrangements in a relapsing fever Borrelia. Cell 41, 403409.

Norgard, M. V. \& Miller, J. N. (1981). Plasmid DNA in Treponema pallidum (Nichols): potential for antibiotic resistance by syphilis bacteria. Science 213, 553-555.

Plasterk, R. H., Simon, M. I. \& Barbour, A. G. (1985). Transposition of structural genes to an expression sequence on a linear plasmid causes antigenic variation in the bacterium Borrelia hermsii. Nature, London 318, 257-263.

Porter, C. D., Porter, A. G. F. \& ARChard, L. C. (1988). BBC microcomputer controlled field inversion gel electrophoresis. Computer Applications in the Biosciences 4, 271-273.

SCHWARTZ, D. C. \& CaNToR, C. R. (1984). Separation of yeast chromosome-sized DNAs by pulsed field gradient gel electrophoresis. Cell 37, 67-75.

SoUTHERN, E. M. (1975). Detection of specific sequences among DNA fragments separated by gel electrophoresis. Journal of Molecular Biology 98, 503-517.

Stoenner, H. G., Dodd, T. \& LaRSEN, C. (1982). Antigenic variation of Borrelia hermsii. Journal of Experimental Medicine 156, 1297-1311.

Van der Ploeg, L. H. T., Cornelissen, A. W. C. A., BARRY, J. D. \& BORST, P. (1984). Chromosomes of kinetoplastida. EMBO Journal 3, 3109-3115. 